\title{
The Degradation of Reactive Brilliant Blue by $\mathrm{Fe}(\mathrm{III}) / \mathrm{H}_{2} \mathrm{O}_{2}$ Systems
}

\author{
Xixi Zuo, Xiaoxia Ou ${ }^{a^{*}}$, Zhiwei Bai, and Shengyuan Xu \\ College of Environment and Resource, Dalian Nationalities University, Dalian 116600, China \\ a *Corresponding author, e-mail address: ouxiaoxia@dlnu.edu.cn
}

Keywords: degradation; Fe(III); dye; hydroxyl radical

Abstract. The degradation of anthraquinone dye reactive brilliant blue (KN-R) by $\mathrm{Fe}(\mathrm{III}) / \mathrm{H}_{2} \mathrm{O}_{2}$ system was investigated in details. The results demonstrated that KN-R was degraded efficiently in the Fenton-like reaction system. $94.40 \%$ removal of $\mathrm{KN}-\mathrm{R}$ in solution $(\mathrm{pH}=3)$ was reached after 40 min when the initial concentrations of $\mathrm{H}_{2} \mathrm{O}_{2}$ and $\mathrm{Fe}(\mathrm{III})$ were $7.5 \mathrm{mmol} / \mathrm{L}$ and $0.5 \mathrm{mmol} / \mathrm{L}$, respectively. And further experiments verified that the main degradation mechanism of $\mathrm{KN}-\mathrm{R}$ was attributed to hydroxyl radical $(\cdot \mathrm{OH})$ attack in the $\mathrm{Fe}(\mathrm{III}) / \mathrm{H}_{2} \mathrm{O}_{2}$ reaction system.

\section{Introduction}

Printing and dyeing industry, as the traditional and preponderant industry of our country, has developed rapidly since 90 years of 20 century. The discharge of dye wastewater has also increased a lot in this industry. According to incomplete statistics, annual emissions of printing and dyeing wastewater are likely to be about 20 million tons, which was nearly the fifth in the total discharge of industrial wastewater in our country.

The printing wastewater is one of the hard-deal industrial wastewater in China because of its large quantity, high organic pollutant content, chromaticity, alkalescence and water quality fluctuation. With the rapid development of dyestuff industry, the dosages of PVA, rayon saponification and a lot of new additives and refractory organic compounds in wastewater are increasing, which makes the wastewater very hard to be treated [1].

Reactive brilliant blue KN-R is classed as the anthraquinone dyes [2], and the chemical formula is $\mathrm{C}_{22} \mathrm{H}_{16} \mathrm{~N}_{2} \mathrm{Na}_{2} \mathrm{O}_{11} \mathrm{~S}_{3}$. The structure formula of it can be described by Fig. 1.

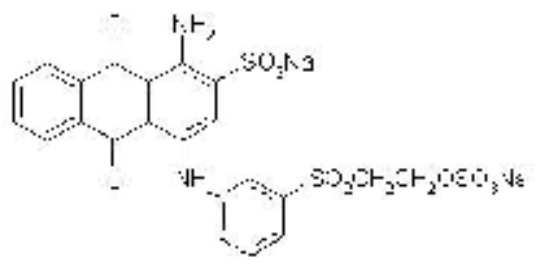

Fig. 1. The structure formula of reactive brilliant blue (KN-R)

At present, $\mathrm{KN}-\mathrm{R}$ is one of the best dyestuff in exhaust dyeing, mainly used for cotton and ramie dyeing. The number of anthraquinone dyes is ranked second only to azo dyes [3]. Due to the highly toxic and nonbiodegradable, the treatment of anthraquinone dyes wastewater is important in the field of ecological environmental protection.

\section{Materials and methods}

Materials. $\mathrm{Fe}\left(\mathrm{NO}_{3}\right)_{3} \cdot 9 \mathrm{H}_{2} \mathrm{O}$ was purchased from Tianjin Kemio Chemical Reagent Co. Ltd and had a purity of $98.5 \%$. $\mathrm{H}_{2} \mathrm{O}_{2}(30 \%)$ was obtained from Tianjin Tianli Chemical Co. Ltd. KN-R stock solution $\left([\mathrm{KN}-\mathrm{R}]_{0}=1000 \mathrm{mg} / \mathrm{L}\right)$ was prepared by dissolving the appropriate amount of $\mathrm{KN}-\mathrm{R}$ in deionized water. A stock solution of $\mathrm{Fe}(\mathrm{III})\left([\mathrm{Fe}(\mathrm{III})]_{0}=100 \mathrm{mM}\right)$ was prepared by dissolving $\mathrm{Fe}\left(\mathrm{NO}_{3}\right)_{3} \cdot 9 \mathrm{H}_{2} \mathrm{O}$ in deionized water that was adjusted to $\mathrm{pH} 3$ by adding $0.1 \mathrm{M} \mathrm{H}_{2} \mathrm{SO}_{4}$. Hydrogen peroxide $\left(\mathrm{H}_{2} \mathrm{O}_{2}\right)$ concentration was prepared and controlled in $1 \mathrm{M}$.

The reaction solution was brought to the appropriate $\mathrm{pH}$ by adding $0.1 \mathrm{M} \mathrm{NaOH}$ or $\mathrm{H}_{2} \mathrm{SO}_{4}$. 
Procedures. A certain amount of KN-R, Fe(III) solution and deionized water were filled into the reaction vessel. Degradation experiments were conducted at least twice. Samples were taken out at the given reaction time intervals and the absorbance of KN-R was analyzed by measuring the UV-vis spectra at $\lambda=592 \mathrm{~nm}$ using UV-vis spectrophotometer. In general, the formula of degradation rate is shown as following.

$$
\text { The degradation rate }(\%)=\left(1-\frac{A_{t}}{A_{0}}\right) * 100 \%
$$

Where: $A_{0}$ - the absorbance before reaction; $A_{\mathrm{t}}$ - the absorbance at $\mathrm{t}$ minutes.

The reaction was started by adding the appropriate amount of $\mathrm{H}_{2} \mathrm{O}_{2}(30 \%$, w/w). All experiments were conducted at room temperature $\left(\mathrm{T}=23 \pm 2^{\circ} \mathrm{C}\right)$ and mixed with magnetic stirring apparatus.

\section{Results and discussion}

Variation of the concentration of $\mathbf{H}_{2} \mathbf{O}_{2}$. The initial reaction conditions were $[\mathrm{KN}-\mathrm{R}]_{0}=150 \mathrm{mg} / \mathrm{L}$, $\mathrm{pH}=3,[\mathrm{Fe}(\mathrm{III})]_{0}=0.5 \mathrm{mM},\left[\mathrm{H}_{2} \mathrm{O}_{2}\right]_{0} /[\mathrm{Fe}(\mathrm{III})]_{0}=1 / 1,3 / 1,5 / 1,10 / 1$ and $15 / 1$ and the reaction time is 40 minutes. There were two ways to add $\mathrm{H}_{2} \mathrm{O}_{2}$. One way was adding $\mathrm{H}_{2} \mathrm{O}_{2}$ in a whole at reaction time of $0 \mathrm{~min}$ and the result is shown in Fig.2a. The other way was adding $\mathrm{H}_{2} \mathrm{O}_{2}$ in five equal portions over initial $20 \mathrm{~min}$, and the result is shown in Fig.2b.

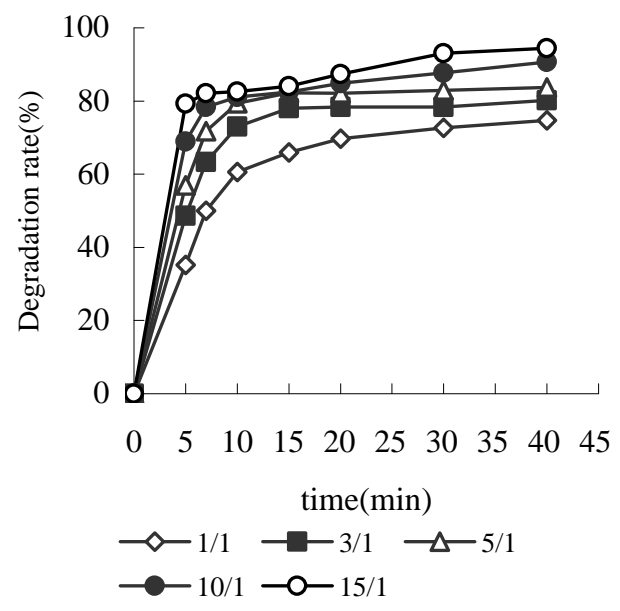

(a)

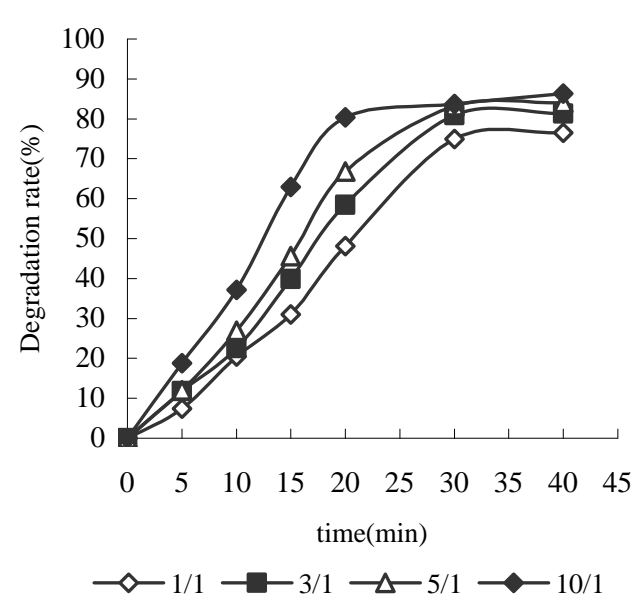

(b)

Fig. 2. Influence of $\mathrm{H}_{2} \mathrm{O}_{2}$ dosage on the degradation of $\mathrm{KN}-\mathrm{R}$ (a) $\mathrm{H}_{2} \mathrm{O}_{2}$ was added in a whole. (b) $\mathrm{H}_{2} \mathrm{O}_{2}$ was added in five equal portions over initial $20 \mathrm{~min}$.

From the Fig. 2a, it shows that when the initial concentration of $\mathrm{H}_{2} \mathrm{O}_{2}$ was in a range of 0.5-7.5mM, the KN-R degradation rate increased with increasing $\mathrm{H}_{2} \mathrm{O}_{2}$ dosage and reached a plateau at 20 minutes. After $40 \mathrm{~min}$, the degradation rate of $\mathrm{KN}-\mathrm{R}$ are $74.74 \%, 80.18 \%, 83.75 \%, 90.66 \%$ and $94.40 \%$, respectively. It's probably because the production of hydroxyl $\operatorname{radical}(\cdot \mathrm{OH})$ which works better in the degradation of KN-R. Possible equations are as follows.

$$
\begin{aligned}
& \mathrm{Fe}(\mathrm{III})+\mathrm{H}_{2} \mathrm{O}_{2} \rightarrow \mathrm{Fe}(\mathrm{II})+\mathrm{HO}_{2} \bullet+\mathrm{H}^{+} \\
& \mathrm{Fe}(\mathrm{II})+\mathrm{H}_{2} \mathrm{O}_{2} \rightarrow \mathrm{Fe}(\mathrm{III})+\mathrm{HO}^{-}+\mathrm{HO}^{\bullet}
\end{aligned}
$$

The equations show that the degradation of $\mathrm{KN}-\mathrm{R}$ has been caused mainly by the Fenton reaction in $\mathrm{Fe}(\mathrm{III}) / \mathrm{H}_{2} \mathrm{O}_{2}$ system. It is reported that the rate of reaction 1 is slower significantly compared to the rate of reaction $2[4,5]$. Accordingly, at the certain initial concentration of $\mathrm{Fe}(\mathrm{III})$, the larger the initial concentration of $\mathrm{H}_{2} \mathrm{O}_{2}$ is, the more [Fe(II)] produces, the greater the degradation rate of $\mathrm{KN}-\mathrm{R}$ is.

Fig. 2b showed the same general trend that the larger the concentration of $\mathrm{H}_{2} \mathrm{O}_{2}$ is, the greater degradation rate of KN-R is. However, by comparison with Fig. 2a, the degradation rate of KN-R at the initial stage from 0 to 10 minutes was greatly reduced. This maybe because the initial 
concentration of $\mathrm{H}_{2} \mathrm{O}_{2}$ at 0 min in Fig. 2b is 1/5 comparing with that of Fig. 2a. Then less $\cdot \mathrm{OH}$ can be produced leading to the loss of degradation.

Variation of the concentration of Fe(III). Fig. 3 shows the effects of Fe(III) dosage from 0.1 to $1.5 \mathrm{mM}$ on the degradation of $\mathrm{KN}-\mathrm{R}$ at $\mathrm{pH} \mathrm{3}$, and the corresponding degradation rate of $\mathrm{KN}-\mathrm{R}$ are $75.96 \%, 79.57 \%, 81.93 \%, 83.48 \%$ and $85.05 \%$, respectively.

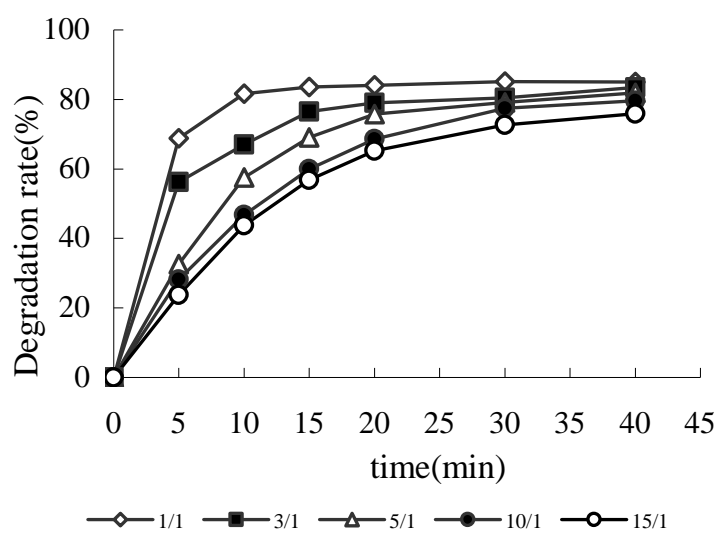

Fig. 3. The effects of initial concentration of $\mathrm{Fe}(\mathrm{III})$ on the degradation rate of KN-R.

$[\mathrm{KN}-\mathrm{R}]_{0}=150 \mathrm{mg} / \mathrm{L},\left[\mathrm{H}_{2} \mathrm{O}_{2}\right]_{0}=1.5 \mathrm{mM}, \mathrm{pH}=3$, reaction time is 40 minutes.

As can be seen from Fig.3, the removal rate of KN-R increased with increasing the initial concentration of $\mathrm{Fe}(\mathrm{III})$. With other condition remaining unchanged, the reaction probabilities between $\mathrm{Fe}(\mathrm{III})$ and $\mathrm{H}_{2} \mathrm{O}_{2}$ increased with the increase of the initial concentration of $\mathrm{Fe}(\mathrm{III})$. Consequently, it can make more of the $\mathrm{Fe}$ (II) to participate in reaction 2 to produce $\cdot \mathrm{OH}$. As the reaction went on, it's can be seen that the Fe(III) is not consumed, and the catalytic cycle between $\mathrm{Fe}(\mathrm{II})$ and $\mathrm{Fe}(\mathrm{III})$ is formed. Bring the concentration of $\mathrm{Fe}(\mathrm{III})$ from $0.1 \mathrm{mM}$ to $1.5 \mathrm{mM}$, the KN-R degradation did not change obviously at the reaction time of $40 \mathrm{~min}$, indicating that $\mathrm{H}_{2} \mathrm{O}_{2}$ has become the limiting factor for reaction. The results of the experiments have shown that the concentration of $\mathrm{H}_{2} \mathrm{O}_{2}$ had expected to be the rate-limiting step for the production of $\cdot \mathrm{OH}$ in $\mathrm{Fe}(\mathrm{III}) / \mathrm{H}_{2} \mathrm{O}_{2}$ systems throughout the whole course of the reaction.

Variation of the solution pH. The effects of $\mathrm{pH}$ on the degradation rate of $\mathrm{KN}-\mathrm{R}$ in $\mathrm{Fe}(\mathrm{III}) / \mathrm{H}_{2} \mathrm{O}_{2}$ system are shown in Fig.4. The initial reaction conditions were $[\mathrm{KN}-\mathrm{R}]_{0}=150 \mathrm{mg} / \mathrm{L}$, $\left[\mathrm{H}_{2} \mathrm{O}_{2}\right]_{0}=7.5 \mathrm{mM}$ and $[\mathrm{Fe}(\mathrm{III})]_{0}=0.5 \mathrm{mM}$ at reaction time of 40 minutes.

As can be seen from Fig.4, the rate of the reaction decreases with increasing $\mathrm{pH}$ in the $\mathrm{Fe}(\mathrm{III}) / \mathrm{H}_{2} \mathrm{O}_{2}$ system. It is well known that $\mathrm{pH}$ obviously has an effect on the oxidation capacity of Fenton-like system. Higher $\mathrm{pH}$ can destabilize $\mathrm{H}_{2} \mathrm{O}_{2}$ [6,7]. The decomposition of $\mathrm{H}_{2} \mathrm{O}_{2}$ would occur at higher $\mathrm{pH}$, and $\mathrm{H}_{2} \mathrm{O}$ and $\mathrm{O}_{2}$ were formed (reaction 3). So higher $\mathrm{pH}$ can lower the concentration of $\mathrm{H}_{2} \mathrm{O}_{2}$ as well as the $\mathrm{KN}-\mathrm{R}$ degradation rate.

$$
2 \mathrm{H}_{2} \mathrm{O}_{2} \rightarrow 2 \mathrm{H}_{2} \mathrm{O}+\mathrm{O}_{2}
$$

Secondly, $\mathrm{pH}$ has an important influence on the form of Fe(III) in the water. Therefore, suitable media $\mathrm{pH}$ probably favours the progress of reaction. In the proper acidic solution, the Fe(III) exists in the form of ferri ion which is better for reaction between $\mathrm{Fe}(\mathrm{III})$ and $\mathrm{H}_{2} \mathrm{O}_{2}$. However, the $\mathrm{Fe}$ (III) exists in the form of $\mathrm{Fe}(\mathrm{OH})_{2}{ }^{+}$at high $\mathrm{pH}$ [8]. It can reduce the concentration of $\mathrm{Fe}(\mathrm{III})$ ions, resulting in the reaction probabilities between $\mathrm{Fe}(\mathrm{III})$ and $\mathrm{H}_{2} \mathrm{O}_{2}$ reducing.

Experiment of free radical quenching. $\cdot \mathrm{OH}$, one of reactive oxygen species, had perfect oxidizing ability. It has been ascribed to can react with biomacromolecules because of its advantages such as efficient oxidation and great potential for rapid reaction. We assumed that the degradation mechanism of $\mathrm{KN}-\mathrm{R}$ was the degraded by $\cdot \mathrm{OH}$ in $\mathrm{Fe}(\mathrm{III}) / \mathrm{H}_{2} \mathrm{O}_{2}$ system though the above analysis. With the rest of the conditions unchanged, $\mathrm{KI}$, the quencher of $\cdot \mathrm{OH}$, is added, and the variation of the degradation rate of KN-R was studied (Fig. 5). 


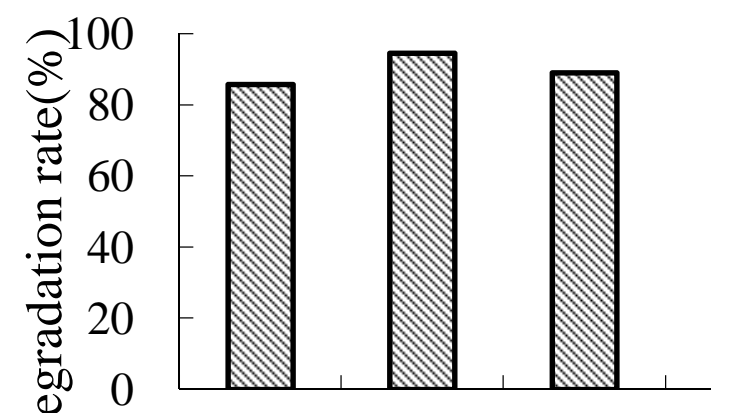

Fig.4. The effects of $\mathrm{pH}$ on the degradation rate of $\mathrm{KN}-\mathrm{R}$ in $\mathrm{Fe}(\mathrm{III}) / \mathrm{H}_{2} \mathrm{O}_{2}$ system $\left([\mathrm{KN}-\mathrm{R}]_{0}=150 \mathrm{mg} / \mathrm{L},\left[\mathrm{H}_{2} \mathrm{O}_{2}\right]_{0}=7.5 \mathrm{mM}\right)$

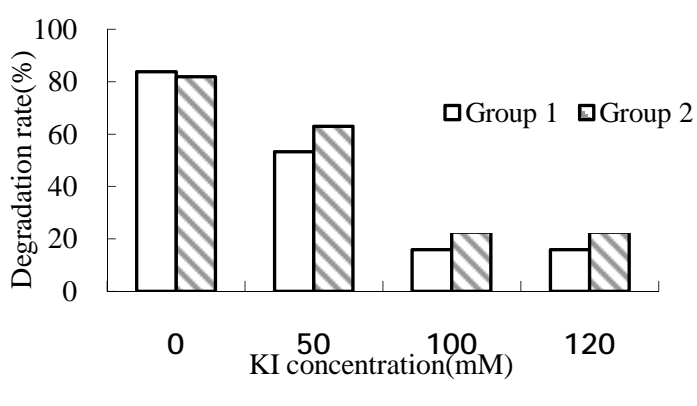

Fig. 5. Effects of the concentration of KI on the degradation rate of $\mathrm{KN}-\mathrm{R}$ in $\mathrm{Fe}(\mathrm{III}) / \mathrm{H}_{2} \mathrm{O}_{2}$ systems

There are two groups experiments in Fig. 5. The conditions of $2.5 \mathrm{mM}\left[\mathrm{H}_{2} \mathrm{O}_{2}\right]_{0}$ and $0.5 \mathrm{mM}$ $[\mathrm{Fe}(\mathrm{III})]_{0}$ were controlled in Group 1 , and $1.5 \mathrm{mM}\left[\mathrm{H}_{2} \mathrm{O}_{2}\right]_{0}$ and $0.3 \mathrm{mM}[\mathrm{Fe}(\mathrm{III})]_{0}$ were controlled in Group 2. The concentration gradient of KI for $50 \mathrm{mM}, 100 \mathrm{mM}$ and $120 \mathrm{mM}$ were used in each group sets. In Fig. 5, when KI is added, it is found that the degradation rate of KN-R drops rapidly with increasing the concentration of KI. The degradation rate of KN-R has remained unchanged when continue to increase the concentration of KI from 100 to $120 \mathrm{mM}$. Group 1 reduces by $67.84 \%$, and Group 2 reduces by $59.44 \%$ with the presence of $100 \mathrm{mM} \mathrm{KI}$. This reflects that $\cdot \mathrm{OH}$ which produced in $\mathrm{Fe}(\mathrm{III}) / \mathrm{H}_{2} \mathrm{O}_{2}$ system are quenched by $\mathrm{KI}$, confirming that the degradation mechanism of KN-R was degraded by $\cdot \mathrm{OH}$ in the $\mathrm{Fe}(\mathrm{III}) / \mathrm{H}_{2} \mathrm{O}_{2}$ system. However, we can find there are still $20 \% \mathrm{KN}-\mathrm{R}$ degraded by adding 100 or $120 \mathrm{mM} \mathrm{KI}$. This indicated that there are other reactive species produced in $\mathrm{Fe}(\mathrm{III}) / \mathrm{H}_{2} \mathrm{O}_{2}$ system to degrade $\mathrm{KN}-\mathrm{R}$. This species might relate to $\mathrm{HO}_{2} \bullet$ (reaction 1 and 2 ).

\section{Conclusions}

In $\mathrm{Fe}(\mathrm{III}) / \mathrm{H}_{2} \mathrm{O}_{2}$ system, the degradation rate of $\mathrm{KN}-\mathrm{R}$ increased with increasing concentrations of $\mathrm{Fe}(\mathrm{III})$ and $\mathrm{H}_{2} \mathrm{O}_{2} .94 .40 \%$ degradation of $\mathrm{KN}-\mathrm{R}$ was reached after 40 min in solution ( $\mathrm{pH}=3$ ) containing $0.5 \mathrm{mmol} / \mathrm{L} \mathrm{Fe}(\mathrm{III})$ and $7.5 \mathrm{mmol} / \mathrm{L} \mathrm{H}_{2} \mathrm{O}_{2}$. The way of adding $\mathrm{H}_{2} \mathrm{O}_{2}$ has the effect on the degradation rate of $\mathrm{KN}-\mathrm{R}$, especially for the initial reaction stage. The degradation mechanism of $\mathrm{KN}-\mathrm{R}$ was mainly degraded by $\cdot \mathrm{OH}$ in the $\mathrm{Fe}(\mathrm{III}) / \mathrm{H}_{2} \mathrm{O}_{2}$ system.

\section{Acknowledgements}

This work was financially supported by the National Natural Science Foundation (No. 21477017), the Fundamental Research Funds for the Central Universities (No.DC201502070202), Student's Platform for Innovation and Entrepreneurship Training Program (No. XA 201712026347) and Student's Taiyangniao Program (No.tyn2017316).

\section{References}

[1] Z.Q. Yang: Water Resources Protection Vol. 20 (2004), p. 66

[2] P. Zhang, B.H. Liao and K.L. Li: Chinese J. Environ. Engineering Vol. 8 (2014), p. 581

[3] T.Z. Sun, Y. Yang and Y. Yao: Journal of Dalian Nationalities University Vol. 14 (2012), p. 1

[4] J. Pignatello, J.E. Oliveros and A. Mackay: Crit. Rev. Environ. Sci. Technol Vol. 36 (2006), p. 1

[5] C.C. Konstantinos, L. Maria and D. Yiannis: Journal of Environmental Chemical Engineering Vol. (2015)

[6] A. Zhang, Y.M. Li: Science of the Total Environment Vol. 493 (2014), p. 307

[7] X.X. Ou, C. Wang and H.J. Sun: Textile Auxiliaries Vol. 1 (2014), p. 28

[8] C. Zeng, Y.F. Ji and L. Zhou: Journal of Hazardous Materials Vol. 239-240 (2012), p. 340 